Katarzyna Wala, Kamil Pietrowiak

Uniwersytet Wrocławski

\title{
Antropologia zmysłów i sensoryczna etnografia - geneza, założenia, podejścia badawcze
}

$\mathrm{W}$ niniejszym tekście przybliżamy inspiracje, początki oraz rozwój ogólnie pojętej antropologii zmysłów, rozumianej bardziej jako obszar naukowych i badawczych zainteresowań, niż ugruntowana subdyscyplina w ramach antropologii kulturowej. Artykuł w żadnym stopniu nie rości sobie pretensji do dokładnego i pełnego omówienia prac przedstawicieli tego nurtu. Naszym celem jest jedynie ukazanie najważniejszych autorów i badaczy, którzy mają wyraźny wpływ na antropologiczną debatę dotyczącą ludzkiej zmysłowości i percepcji oraz jej powiązań z kulturą czy porządkiem społecznym. Pragniemy ukazać ogólne możliwości tego rodzaju namysłu w ramach antropologii kulturowej, a także zasadnicze różnice między autorami podejmującymi tego rodzaju badania. Tym samym poniższy artykuł można potraktować jako poręczne wprowadzenie do niniejszego tomu, prezentujące podstawowe możliwości i ograniczenia antropologicznych i etnograficznych badań nad zmysłami.

\section{Antropologia wobec tematyki zmysłów}

Antropologiczny namysł nad zmysłami nie jest zjawiskiem nowym, jego przejawy można odnaleźć już w klasycznych pracach etnograficznych, do których odwołują się współcześni badacze, poszukujący w publikacjach swych poprzedników podstaw dla rozwoju omawianej subdyscypliny. Constance Classen (1997), David Howes (2003) oraz Anthony Synnott (1993) dowodzą, że problematyka ludzkiej zmysłowości nie była obca XIX-wiecznym etnografom i antropologom, 
zafascynowanym nie tylko osobliwościami kulturowymi, lecz również fizycznymi i sensorycznymi właściwościami przedstawicieli egzotycznych plemion (Howes 2003: 4). Ich zdaniem zainteresowanie to wyrastało z ewolucjonistycznej tendencji do klasyfikowania ludzi według cech fizycznych przypisanych poszczególnym rasom (Synnott 1993: 145). Ewolucjoniści zakładali, że kultury ludzkie kształtowały się według jednej zasady - od szczebli niższych do wyższych, przechodząc w różnym tempie przez te same etapy rozwoju. W powszechnym wówczas przekonaniu Europejczyk - czy szerzej: biały człowiek - był istotą racjonalną, mieszkańców pozostałych kontynentów łączono natomiast z cielesnością, witalnością i sensualnością (Howes 2003: 11). Dziewiętnastowieczny przyrodnik Lorenz Oken stworzył nawet swoistą hierarchię, łącząc przedstawicieli poszczególnych ras z określonym organem zmysłowym. Na jej szczycie znalazł się Europejczyk - „człowiek-oko”, zaraz za nim Azjata - „człowiek-ucho”, dalej rdzenny mieszkaniec Ameryki - „człowiek-nos” i Australijski „,człowiek-język”; na sam dół hierarchii zepchnięty został afrykański „człowiek-skóra” (Classen 1997: 405; Howes 2003: 5). Tak skonstruowana hierarchia zmysłów i ras nie odnosiła się do wrodzonych cech opisywanych ludzi. Zamiast tego stanowiła dokładne odzwierciedlenie ich pozycji w świadomości XIX-wiecznej inteligencji europejskiej (Howes 2012), według której uprzywilejowaną rolę w zmysłowym poznaniu świata pełni wzrok, od czasów Arystotelesa łączony z racjonalnością.

W czasach dominacji antropometrii i kraniometrii pojawiały się również propozycje pomiarów zdolności sensorycznych. W latach 1898-1899 Alfred Haddon prowadził ekspedycję Torres Straits Expedition, podczas której zamierzał zbadać stopień rozwinięcia dyspozycji zmysłowych wśród „prymitywnych” mieszkańców Cieśniny Torresa. Testom podlegała „ostrość widzenia, wrażliwość na światło, widzenie kolorów, włączając w to zdolność rozpoznawania barw, (...) percepcję przestrzeni wizualnej, ostrość i zakres słyszenia, świadomość różnicy tonów i rytmów" (Haddon 1978, za: Synnot 1993: 145; por. Haddon 1903). Końcowy raport z badań potwierdzał trafność klasycznych dychotomii: ciało i rozum, dzikość i cywilizacja (Howes 2003: 5).

Po I wojnie światowej nastąpiło ograniczenie liczby badań opartych na antropometrii, które uznano za niewłaściwe i sprzyjające rasizmowi. Tendencja ta nasiliła się po 1945 roku. Dodatkowo dla antropologii, która aspirowała do statusu poważnej nauki, zmysły i sensualność - w odróżnieniu od systemów pokrewieństwa, struktur politycznych czy wierzeń religijnych - stanowiły raczej błahy temat do rozważań (Synnot 1993: 4). Istniały jednak pewne odstępstwa od tej normy. Jak wskazuje Howes, w latach 30. XX wieku badacze zaczęli dostrzegać związek pomiędzy postrzeganiem zmysłowym a kulturą (Howes 2003: 10). Kluczową rolę odegrali w tym wypadku przedstawiciele amerykańskiej szkoły kultury i osobowości, którzy oddalili się od idei ewolucjonistycznych oraz zaczęli analizować różnice między różnymi społecznościami przez pryzmat wartości kulturowych (Howes 2003: 145). Kładli oni nacisk na całościowe badanie kultur, poszukiwali logicznego powiązania postulatów, twierdzeń czy idei, którym podporządkowano wzory zachowań obowiązujące w danej kulturze oraz decydujące 
o jej niepowtarzalności. Układ ten nazywali wzorem, stylem, konfiguracją czy konstelacją. W ich przekonaniu kultury różnią się przede wszystkim swoją orientacją - niektóre społeczeństwa są nastawione na czerpanie przyjemności, inne na prowadzenie wojny, jeszcze inne na pracę (por. Olszewska-Dyoniziak 2003: 196). Jedną z czołowych przedstawicielek tego kręgu była Ruth Benedict, która odniosła się bezpośrednio do tematyki sensualności w książce Chryzantema i miecz. Wzory kultury Japońskiej (1946), ukazując, że sposoby korzystania ze zmysłów mają swoje źródło w kulturze i jako takie zostają przekazywane i przyswajane $\mathrm{w}$ procesie akulturacji:

Zaskakuje przychylność, z jaką japoński kodeks moralny podchodzi do uciech pięciu zmysłów. (...) Japończycy nie są purytanami i nie odżegnują się od przyjemności. Przeciwnie - uważają rozkosze ciała za dobro, którego uprawianiu warto się oddawać, szukają ich i cenią wysoko. Muszą one jednak mieć swój czas oraz miejsce i nie mogą zakłócać biegu spraw prozaicznych. Zasady te sprawiają, że człowiek żyje w ogromnym napięciu. Następstwa japońskiej akceptacji rozkoszy zmysłowych o wiele łatwiej dostrzeże Hindus niż Amerykanin. Ten ostatni uważa bowiem, że rozkoszy nie można się nauczyć, i sądzi, że człowiek, odrzucając folgowanie zmysłom, opiera się pokusie czegoś, co dobrze zna. Otóż doznawania rozkoszy człowiek uczy się tak samo jak wypełniania obowiązków (Benedict 1999: 167).

Benedict nadała zupełne nowe znaczenie zmysłom w obrębie antropologii, a także udowadniała, że ludzie żyją w odmiennych porządkach zmysłowych (por. Synnot 1993: 146). Wątek ten został podjęty przez Margaret Mead oraz Rhodę Bubendey Métraux w książce The Study of Culture at a Distance, której wyjątkowość - zdaniem współczesnych komentatorów - polega na podkreśleniu wartości badań dotyczących kulturowych wzorów doświadczenia zmysłowego. Mead i Métraux piszą:

Tak, jak lingwistyka wymaga specjalistycznego ucha, tak analiza kulturowa potrzebuje socjalistycznej obróbki wszystkich zmysłów, odkąd ludzie nie tylko słyszą, mówią i komunikują się poprzez słowa, ale także używają pozostałych zmysłów (...), smakują i wąchają zgodnie ze wzorem smakowania i czucia, dzięki czemu tradycyjna kuchnia jest dystynktywna i zorganizowana podobnie jak język (Mead, Métraux 1953: 16).

Z kolei sama Métraux prezentuje wytyczne do badań nad kulturowym sensorium. Według autorki ludzie postrzegają świat jako „koherentną całość” - aby zatem pojąć, w jaki sposób jest ona kształtowana przez wyobraźnię sensoryczną, niezbędne jest rozwinięcie „świadomości dwóch systemów, wewnątrz których pracujemy - systemu percepcji kultury, w której prowadzone są badania i tej, z której pochodzi badacz" (Métraux 1953: 11). Métraux i Mead starają się wyraźnie dyscyplinować własne sposoby postrzegania, aby nie wpływały one na analizę alternatywnych wzorów doświadczania zmysłowego (Howes 2003: 12). Co prawda podejście reprezentowane przez antropolożki można uznać za 
refleksyjne, to jednak z punktu widzenia współczesnej antropologii jest ono dość zachowawcze. Autorki nie zastanawiają się, w jakim zakresie własne strategie postrzegania mogą wpływać na poczynione w terenie obserwacje. Starają się raczej obiektywizować je poprzez rozdwojenie własnej świadomości, tworząc, a zarazem przekraczając drugie „ja”. Takie podejście do analizy kulturowej można określić jako przebywanie w dwóch porządkach sensorycznych (being of two sensoria) (Howes, Classen 1991: 260).

Oprócz wymienionych autorek ważny wpływ na rozwój tego rodzaju badań miał również Edward T. Hall, który skoncentrował się na kulturowym charakterze percepcji. Jak pisał:

Przez długie lata sądzono, że doświadczenie jest czymś jednoczącym wszystkich ludzi, że zawsze można niejako wyminąć język i kulturę i zwrócić się ku doświadczeniu po to, by osiągnąć porozumienie z inną jednostką. Ten milcząco przyjęty (choć często wyrażany explicite) pogląd o związku między człowiekiem a doświadczeniem opiera się na założeniu, że wówczas, gdy dwie osoby są podmiotami tego doświadczenia, to w istocie dwa układy nerwowe zasilane są przez te same dane, dwa mózgi podobnie je rejestrują. Badania proksemiczne każą poważnie wątpić w to założenie, zwłaszcza w tych wypadkach, gdzie mamy do czynienia z różnymi kulturami. (...) Ludzie z odmiennych kręgów kulturowych nie tylko mówią odrębnymi językami, lecz również - co prawdopodobnie ważniejsze-przebywają w odrębnych rzeczywistościach zmysłowych (Hall 2009: 12-13).

Zdaniem antropologa to, w jaki sposób poszczególne jednostki doświadczają różnego rodzaju przestrzeni, jest określone przez normy kulturowe i przyswajane w procesie enkulturacji: „Ludzie urodzeni w różnych kulturach uczą się (nie wiedząc o tym) już jako dzieci pomijać informacje jednego rodzaju i zwracać baczną uwagę na inne. Owe wzorce percepcyjne, raz ustalone, utrwalają się na całe życie" (Hall 2009: 70). Równocześnie uważa on, że podobne różnice sięgają głębiej i uwidaczniają się także w relacjach między członkami tej samej kultury. Jego zdaniem „mężczyźni i kobiety żyją w zupełnie różnych światach wizualnych. Są to różnice, których nie można złożyć na karb różnorakiej ostrości widzenia. Po prostu mężczyźni i kobiety nauczyli się posługiwać wzrokiem w odmienny sposób" (Hall 2009: 103).

Według Halla wyraźnym przykładem odmienności zmysłowych rzeczywistości są sposoby orientowania się w przestrzeni oraz przemieszczania się z miejsca na miejsce. Do podobnych wniosków doszedł również Edmund Carpenter, opisujący percepcyjny świat Eskimosów jako formę kulturowego przystosowania się do warunków środowiskowych oraz specyfiki polarnego krajobrazu. W Arktyce horyzont bywa niewidoczny, a ziemia i niebo zdają się być jedną substancją, stąd też, jak pisze antropolog:

nie ma żadnego drugiego planu, perspektywy, zarysu; oko nie ma się na czym zatrzymać z wyjątkiem tysięcy dymiących pióropuszy śniegu biegnących przed wiatrem do ziemi - jest to kraj bez krawędzi i brzegów. Gdy zerwie się wiatr, 
wypełniając powietrze śniegiem, widoczność zostaje ograniczona do maksymalnie dziewięciu metrów (Carpenter, Varley, Flaherty 1958, za: Hall 2009: 114).

Zestawiając arktyczny pejzaż z dobrze znanym sobie obrazem amerykańskiego miasta, badacz pisze:

Gdy jadę samochodem, mogę stosunkowo łatwo przejechać przez trudne do zorientowania się i chaotyczne miasto w rodzaju Detroit, kierując się po prostu kilkoma znakami drogowymi; zakładam, że ulice układają się w rodzaj kratownicy, i wiem, że pewne znaki wyznaczają moją trasę. Eskimosi Aivilik mają oczywiście podobne, choć naturalne, punkty odniesienia. Nie są to na ogół rzeczywiste przedmioty lub punkty, lecz raczej relacje; powiązania pomiędzy na przykład konturem i typem śniegu, wiatrem, słonym powietrzem, pęknięciem lodu (Carpenter, Varley, Flaherty 1958, za: Hall 2009: 114).

Carpenter opisuje kulturę Aivilik jako „świat, w którym oko słyszy, ucho widzi, a wszystkie pięć zmysłów uczestniczy w koncercie przeplatających się rytmów" (Carpenter 1972: 31, za: Prins, Bishop 2001: 116). Antropolog rozwija przy tym koncepcję przestrzeni akustycznej (auditory space), starając się uchwycić jej zmienność:

Przestrzeń akustyczna nie posiada uprzywilejowanego źródła. To sfera bez ustalonych granic (...). Nie ma charakteru obrazkowego, nie jest skrystalizowana lecz dynamiczna, płynna, pozbawiona nieciągłości, tworzy swój własny wymiar. (...) Oko precyzuje, wskazuje, streszcza, lokalizując każdy obiekt w przestrzeni fizycznej, odróżniając go w ten sposób od tła; ucho natomiast przyjmuje dźwięki dochodzące z każdej strony. Nie znam Eskimosa, który opisywałby przestrzeń w terminach wyłącznie wizualnych (Carpenter 1972: 31, za: Prins, Bishop 2001: 116).

Tego rodzaju tropy zostają rozwinięte w pracach jego towarzysza i współpracownika Marshalla McLuhana - teoretyka mediów, badającego mechanizmy zmian kulturowych w zakresie postrzegania, a także wpływ sposobów komunikacji i technologii informacyjnych na ludzką podmiotowość i wspólnotowość (McLuhan 2010: 95). Osią jego teorii jest determinizm technologiczny - zgodnie z tym podejściem techniczne wynalazki prowadzą do zmiany kulturowej, każdorazowo wpływają na zakres, rolę oraz sposoby działania naszych zmysłów, a także wprowadzają szereg nowych relacji w obrębie codziennych doświadczeń, zmieniając w ten sposób świadomość i stwarzając nowe modele uczestnictwa w świecie. Swoje zasadnicze przekonanie zawarł w lapidarnej formule: „środek jest przekazem" (medium is a message). Jak podsumowuje to Tomasz Misiak:

to właśnie środek jest czynnikiem kształtującym i kontrolującym zakres i formę działalności ludzkiej. Treść, czyli sposoby wykorzystania tego rodzaju środków, jest różnorodna, ale nieefektywna w procesie kształtowania form i stosunków między ludźmi (Misiak 2007). 
Według McLuhana jesteśmy kształtowani w większym stopniu przez rodzaj mediów, za pomocą których się komunikujemy, niż przez samą treść komunikacji (Misiak 2007). Gdy w wiosce plemiennej dominowała akustyka, zmysły słuchu, dotyku, smaku i węchu rozwijały się znacznie bardziej niż umiejętności wizualne. Pojawienie się alfabetu fonetycznego doprowadziło do zburzenia tego świata. Gęsie piórko, maszyny i energia elektryczna zmieniły nasz system sensoryczny, a razem z nim całą cywilizację. Ludzie posiadający umiejętność czytania „wymienili ucho na oko”, co dało początek kształtowaniu się „społeczeństwa wizualnego", gdyż to właśnie dzięki pismu możliwe stało się opuszczenie plemienia bez utraty dostępu do źródeł informacji. Korzystając z pisma, człowiek uzależnił się od doznań wizualnych, natomiast prasa drukarska upowszechniła to zjawisko.

Równocześnie kanadyjski badacz przewidywał, że media elektroniczne doprowadzą do ponownych podziałów plemiennych, zaś natychmiastowa komunikacja przywróci nas do stanu prealfabetycznej tradycji oralnej, w której dźwięk i dotyk mają wyższą wartość niż wzrok ${ }^{1}$. Zgodnie z tym poglądem jesteśmy członkami jednej wielkiej globalnej wioski (global village):

planeta wygląda niczym jarmark, na którym hałaśliwi ludzie śledzą sprawy innych - dyskusja w Internecie, czy kolejny talk-show połączony z audiotele; obywatele świata ponownie znaleźli się w przestrzeni akustycznej i dotykowej (McLuhan 2001: 6).

Badania nad czynnikami kształtującymi ludzkie sensorium prowadził także uczeń McLuhana Walter Ong, który analizował związki zachodzące między zwiększoną aktywnością słuchową a cechami kultur oralnych, a także kwestię alienacji i reintegracji świadomości wynikającą z rozwoju środków technologicznych. Jego zdaniem bez zrozumienia specyfiki samego dźwięku nie można wyjaśnić specyfiki kultur oralnych - „ograniczenie słowa do dźwięku określa w kulturze oralnej nie tylko sposób wyrażania, lecz także procesy myślowe” (Ong 2003: 192). Jedną z istotnych cech dźwięku jest jego związek z czasem:

Mogę zatrzymać pracę kamery filmowej i pokazywać na ekranie jedno ujęcie. Zatrzymując ruch dźwięku nie mam niczego - jedynie ciszę (...) I choć wszystkie doznania zmysłowe rozgrywają się w czasie, to żadne inne nie jest tak odporne wobec działań zatrzymujących, stabilizujących. Widzenie pozwala zarejestrować ruch, może jednak rejestrować bezruch. Więcej nawet, widzenie preferuje bezruch, oglądając bowiem coś dokładnie, wolimy, by pozostawało nieruchome. Często sprowadzamy ruch do serii kolejnych ujęć, by lepiej zrozumieć czym jest ruch. Nie istnieje odpowiednik „serii ujęć” dla dźwięku. Oscylogram jest cichy (Ong 1992: 56).

1 McLuhan zamierzał wykorzystać swoje pomysły w praktyczny sposób, tworząc test umożliwiający ustalanie sensorycznej typologii - zarówno jednostek, jak i całych kultur. Wierzył, że pozwoli to zrewolucjonizować edukację, reklamę i politykę, zapobiegać niedoborom sensorycznym i usprawnić komunikację. Projekt nigdy się nie rozpoczął, częściowo ze względu na brak funduszy (Synnott 1993: 150). 
W 1967 roku Ong przedstawił koncepcję sensorium, odnosząc to pojęcie do całości sensorycznych zdolności człowieka (Ong 1967: 6). Jak pisał w kolejnych pracach: „Kultury różnią się w znacznej mierze w kwestii czynienia użytku z różnych zmysłów, jak również co do sposobów, w jaki do nich odnoszą swój aparat poznawczy" (Ong 1967: 3). Doznania zmysłowe są tak bogate, że nie ma ani jednostki, ani kultury, która byłaby w stanie korzystać z nich w całości każda musi dokonać selekcji i wtórnego opracowania (por. Sendyka 2011: 26). Zdaniem Onga wybór ten jest określony przez czynniki kulturowe; w niektórych społeczeństwach poświęca się więcej uwagi informacjom wizualnym, w innych dźwiękowym - dzieci od najmłodszych lat uczą się postępować według wskazówek podyktowanych przez tradycję. Uznał on, że ludzkie sensorium układa się w sekwencję zmysłów: dotyk - smak - węch - słuch - wzrok (Ong 1977: 36, za: Synnott 1993: 152). Czytana od lewej strony do prawej ukazuje ona zwiększenie dystansu między odbiorcą a obiektem, a także nasilenie abstrakcji i formalizacji w obrębie ich relacji. Z kolei ruch w przeciwnym kierunku zwraca nas ku konkretności i subiektywności. Według Onga wszystkie tradycyjne kultury przyporządkowane są lewej stronie kontinuum, natomiast społeczeństwa nowoczesne plasują się po jego prawej stronie.

W tym samym czasie gdy McLuhan rozwijał teorię porządków sensorycznych $^{2}$ (theory of sensory ratios), Claude Lévi-Strauss pracował nad założeniami logiki konkretu (science of the concrete). Jak streszcza poglądy francuskiego antropologa Edmund Leach (2010: 10), świat zewnętrzny jest „wiadomy na tyle, na ile pozwalają nam na to zmysły. Jednocześnie zjawiska, które postrzegamy, mają tylko te cechy, które możemy im przypisać, dlatego, że działanie naszych zmysłów i konstrukcja mózgu pozwala, by mogły porządkować i interpretować odbierane bodźce". Metoda stosowana przez Lévi-Straussa polegała na niedowierzaniu bezpośredniemu doświadczeniu oraz poszukiwaniu ukrytego porządku, który nadaje sens pozornie trywialnym lub bezsensownym zjawiskom i słowom. Zainspirowany ideałami synestetycznymi XIX-wiecznych symbolistów, w tym Arthura Rimbaud, antropolog podjął się badań nad kodami mitów zmysłowych. W pierwszym tomie Mitologii, w części zatytułowanej Fuga pięciu zmysłów (Lévi-Strauss 2010: 151-167), pokazuje on, w jaki sposób wrażenia odczuwane w jednej modalności mogą się przenieść na inną modalność, łącząc się jednocześnie z pojęciami ułożonymi w szeregi opozycji binarnych, np. życie i śmierć, natura i kultura (por. Herzfeld 2004: 342).

Seria trzech „wołań” w odwrotnym porządku odsłania podział pożywienia na trzy kategorie: rolnictwo, polowanie, kanibalizm. Co więcej, te trzy kategorie, które można nazwać "smakowymi”, zostały zakodowane w terminach innego systemu zmysłowego, mianowicie słuchowego. I wreszcie, zastosowane symbole słuchowe mają godną uwagi właściwość: natychmiast nasuwają myśl o dwóch

2 Carpenter, McLuhan oraz Ong, badając zmiany w obrębie kulturowego sensorium, uważali, że świat jest możliwy do wyjaśnienia i doświadczenia na różne sposoby, w zależności od porządku zmysłowego, który jest podzielany przez członków danej kultury (por. Howes 1991a: 8). 
innych rodzajach kodowania zmysłowego, węchowym i dotykowym (...). W ten sposób grupa równoważności łączących życie i śmierć, pożywienie roślinne i kanibalizm, zepsucie i niezepsucie, miękkość i twardość, ciszę i hałas staje się jedną całością (Lévi-Strauss 2010: 157).

Lévi-Straussa interesują relacje, jakie zachodzą pomiędzy zmysłami; jednocześnie - o czym pisze Howes - podkreśla on raczej kontrasty, homologie, opozycje binarne niż porządki, hierarchie czy wzajemne oddziaływanie zmysłów sugerowane przez McLuhana, Onga czy Carpentera (Howes 2003: 16). Francuski antropolog nie analizował również kodów sensorycznych kultury jako całości (Herzfeld 2004: 343). Jak zauważa Classen (1997: 406), zainteresowany był on raczej „śledzeniem operacji zachodzących w umyśle niż analizą życia społecznego zmysłów". Według Michaela Herzfelda (2004: 343) przyczyny tego należy upatrywać w braku odpowiedniej technologii, która umożliwiałyby rejestrowanie oraz analizę doznań sensorycznych. Stąd też jego zdaniem strukturalne zamiłowanie do podziału zmysłu na "gustemy" - kulturowo znaczące jednostki smaku - nie doprowadziło do wyłonienia się żadnych nowych spostrzeżeń.

Ostatecznie antropologiczna refleksja nad zmysłami bardzo długo stanowiła jedynie margines zainteresowań przedstawicieli dyscypliny. Pojedyncze wątki, teorie, badania nie układają się w jedną całość i pozostają w rozproszeniu aż do końca lat 80. XX wieku, gdy powrócono do perspektywy stworzonej przez Onga i McLuhana w ramach badań nad mediami, rozszerzając ją o analizę historycznych i społecznych sposobów konstruowania sensorium.

\section{Antropologia zmysłów}

Rozwój antropologii zmysłów zbiegł się w czasie z rozkwitem myśli postmodernistycznej. Pierwsze oznaki zmian były widoczne już od lat 70. XX wieku, gdy przedstawiciele dyscypliny z coraz większym zainteresowaniem przyglądali się nowinkom w obrębie badań nad językiem. Antropologia, jak pisze Marcin Brocki (2008: 61), „zaczęła postrzegać samą siebie jako rodzaj pisarstwa”, co zostało wyrażone w często cytowanej, lapidarnej frazie Clifforda Geertza (2003: 49): „ «Co etnograf robi» - on pisze”. Choć powyższych słów nie należy traktować literalnie ${ }^{3}$, to jednak streszczają one podejście, które w latach 80. XX wieku zdominowało debatę antropologiczną, podkreślające problem politycznych i etycznych aspektów pisania kultury. Kolejne prace takich autorów, jak George Marcus, Paul Rabinow czy James Clifford skierowały uwage na - długo banalizowaną w ramach dyscypliny - kwestię strategii reprezentacji wiedzy, czyniąc zeń najważniejszy problem praktyki badań antropologicznych (Brocki 2008: 61).

3 W dalszej części artykułu antropolog dodaje: „Lub, i tym razem dokładniej zapisuje. Etnografia przeważnie mieści się w książkach i artykułach, a nie w filmach, nagraniach, na wystawach muzealnych czy gdzie tam jeszcze, lecz oczywiście nawet $w$ nich odnajdujemy fotografie, rysunki, wykresy, tabele itd. $W$ antropologii bardzo brakuje samoświadomości na temat sposobów przedstawiania (nie mówiąc już o eksperymentowaniu z nimi)" (Geertz 2003: 49). 
Postmoderniści krytykowali modernistów za naiwny realizm, ukrywanie założeń praktyki antropologicznej, prowadzących do asymetrycznej i upolitycznionej relacji z badanymi podmiotami i grupami. Przedstawiciele tego nurtu starali się podważyć procedury badań terenowych prowadzonych przez modernistycznych badaczy, co zaowocowało stopniowym odchodzeniem etnologów od praktyki terenowej (Howes 2003: 17) - przestano bowiem ufać klasycznym sposobom zbierania danych.

Zdaniem Doroty Angutek (2010: 226-227) „dyskusja tocząca się wokół ograniczeń modernistycznych epistemologii przygasła, i choć postmoderniści rozbili modernistyczne epistemologie i taktyki metodyczne, to jednak niewiele zaproponowali w zamian poza dość dziwacznym czasem tekstualizmem". Antropolodzy zmęczeni nadmierną koncentracją na krytyce tekstualnej zaczęli poszukiwać nowych sposobów myślenia, powalających przezwyciężyć impas poznawczy. Cześć z nich zwróciła się w stronę doświadczenia zmysłowego, w którym starano się odnaleźć nowe pierwiastki poznawcze, ważkie dla antropologicznej strategii badawczej.

Nazwa "antropologia zmysłów” (anthropology of the senses) po raz pierwszy pojawiła się w przedmowie do pracy Alana Corbina The Foul and the Fragrant: Odor and the French Social Imagination, napisanej przez Roya Portera, angielskiego historyka kultury i społeczeństwa:

Corbin odnajduje zapachy w nauce, w społecznym podejściu do zdrowia czy w indywidualnej wrażliwości mieszkańców Paryża, jego praca może wzbudzić ogromne zainteresowanie nie tylko wśród specjalistów z zakresu historii, literatury i medycyny, lecz również czytelników zafascynowanych kulturową antropologią zmysłów (Porter 1986: VI-VII).

Porter nie opisuje jednak dokładnie, czym miałaby być owa subdyscyplina. Kulturowa antropologia zmysłów pozostaje pustą kategorią aż do 1988 roku, gdy na Uniwersytecie Concordia w Montrealu zostaje powołany do życia Concordia Sensoria Research Team, skupiający antropologów zajmujących się międzykulturowymi badaniami porównawczymi nad znaczeniem zmysłów. Kierunek rozwoju subdyscypliny wyznaczyły przede wszystkim trzy publikacje: The Taste of Ethnographic Things Paula Stollera (1989), The Veriaties of Sensory Experience: A Sourcebook in the Anthropology of the Senses (1991) pod redakcją Davida Howesa, a także praca Nadii Serementakis The Senses Still. Prception and Memory as Material Culture in Modernity (1994). W naszej ocenie stanowią one fundament dla całej subdyscypliny, zakreślają jej horyzont teoretyczny oraz metodologię badań. Tym, co łączy wymienionych autorów, jest przekonanie, że percepcja zmysłowa - oprócz tego, że posiada wymiar fizyczny - jest także aktem kulturowym (Classen 1997: 401). Antropolodzy z tego kręgu zgodnie wystąpili przeciwko okulocentryzmowi i tekstualizmowi, jaki zdominował antropologię lat 80. i 90. XX wieku. Ich celem stało się zastąpienie jednostronnej, okulocentrycznej epistemologii modernistycznej epistemologią opartą na wielozmysłowym doświadczeniu (Angutek 2010: 227). 
Od samego początku subdyscyplina rozwijała się równolegle w kilku krajach - przede wszystkim Kanadzie i USA, a także w obrębie dwóch naukowych tradycji - w dyscyplinach historycznych i antropologii kulturowej. O ile w Kanadzie pod względem teoretycznym, metodologicznym i organizacyjnym antropologia zmysłów była jasno sprecyzowana, o tyle w Stanach Zjednoczonych posiada ona liczniejsze warianty teoretyczne i wersje autorskie (por. Angutek 2010: 221). Różnorodność istniejących orientacji badawczych odzwierciedlają systematyzacje sporządzone przez Constance Classen (1997: 405-409) i Michaela Herzfelda (2004: 333-334). Porządkując ich rozważania, zdecydowaliśmy się na wyróżnienie trzech zasadniczych nurtów badań nad zmysłami: kanadyjskiej i amerykańskiej antropologii zmysłów, a także wyłaniającej się z krytyki tej pierwszej antropologii sensorycznej ${ }^{4}$.

\subsection{Kanadyjska szkoła antropologii zmysłów}

Wiosną 1988 roku na Uniwersytecie Concordia w Montrealu powołano do życia Concordia Sensoria Research Team, w skrócie Consert. Na czele zespołu stanął antropolog kulturowy i socjolog David Howes, zaś jego najbliższymi współpracownikami okazali się Constance Classen i Anthony Synnott. Ich pierwszy wspólny projekt badawczy - The Varieties of Sensory Experience - zakładał przyglądanie się funkcjonowaniu zmysłów w obrębie życia codziennego przy wykorzystaniu analizy historycznej oraz badań porównawczych. Celem pracy było stworzenie typologii kultur opartej na odmiennych sposobach organizacji i porządkowania doświadczenia zmysłowego. Efekty tych badań zostały zebrane w kolejnych publikacjach Classen (1993) czy Synnotta (1993), a także w specjalnych wydaniach czasopism: "Journal of Religion and Culture" (1990, tom 4, nr 2), "Anthropologie et Sociétés" (1990, tom 14, nr 2) i "Anthropologica” (1990, tom 32, nr 1).

Jednak to właśnie w pracy The Varieties of Sensory Experience: A Sourcebook in the Anthropology of the Senses (1991) po raz pierwszy przedstawiono program antropologii zmysłów. We wstępie do książki Howes (1991a: 3) pisze:

Antropologia zmysłów analizuje, w jaki sposób prawidłowości doświadczenia zmysłowego zmieniają się w zależności od kultury, zgodnie ze znaczeniem i wagą przypisywaną każdemu z percepcyjnych wzorców. Interesuje nas też śledzenie wpływu tego zróżnicowania na formy organizacji społecznej, koncepcje własnego ja i kosmosu, kontrolowanie emocji oraz innych obszarów kulturowej ekspresji. Jedynie pod warunkiem, że wykształcimy w sobie na tym polu wnikliwą świadomość zasad wizualnych i tekstualnych reguł zachodniej episteme, możemy mieć nadzieję, że uda się nam pojąć, jakie znaczenie ma życie w innych kontekstach kulturowych.

4 Nieco inne rozróżnienie zaproponowała Dorota Angutek (2013: 152-202), która obok kanadyjskiej porównawczej antropologii zmysłów omawia osobno fenomenologiczną antropologię i etnografię zmysłów Michaela Jacksona, a także badawcze propozycje Sarah Pink, Nadii Seremetakis i Paula Stollera. 
Kanadyjscy antropolodzy uznają, że percepcja ma podstawy w kulturze, a zatem - jak podsumowuje to Classen (1997: 401) - „(...) jest nie tylko aktem fizycznym, lecz również kulturowym. Wzrok, słuch, dotyk, smak i węch nie są wyłącznie środkiem ujmowania zjawisk fizycznych, lecz również kanałem transmisji wartości kulturowych". Zgodnie z tą perspektywą każda kultura może ujawniać inny wzór ludzkiego sensorium, a także różne hierarchie zmysłów. Antropolodzy udowadniają, że zakorzeniony w myśli zachodniej arystotelesowski porządek zmysłów ${ }^{5}$, w którym uprzywilejowaną rolę pełni wzrok, jest w gruncie rzeczy konstrukcją kulturową, a zatem stanowi jeden z możliwych wariantów. Badacze wskazują na istnienie kultur, w których wyróżnia się większą bądź mniejszą liczbę zmysłów według Iana Ritchiego (1991: 195) członkowie plemienia Hausa wyodrębniają dwa zmysły. Przyglądają się sensorium innego typu - np. mieszkańcy Jawy rozpoznają pięć zmysłów: wzrok, słuch, mowę, węch, czucie (Dundes 1980: 192). Opisują społeczności, w których pewnym zmysłom przypisuje się większe znaczenie niż innym - np. badania Classen (1993: 85) dowodzą, że dominującym zmysłem u Suya z Mato Grasso jest węch. Jednocześnie przyjmują, że porządek sensoryczny danej kultury nie jest statyczny, lecz może zmieniać się w czasie. W ten sposób nawiązują do prac McLuhana, Carpentera i Onga, choć nie bez zastrzeżeń.

Przedstawiciele grupy Consert podkreślają złożony i niejednoznaczny charakter transformacji zachodzących $\mathrm{w}$ obrębie społecznego sensorium (Classen 1993: 1-13). Howes twierdzi, że hierarchie zmysłów, ich liczba i rodzaj, oraz pojęciowe, społeczne i symboliczne przedstawienia jakości zmysłowych, są uwarunkowane przede wszystkim tradycją i zdeterminowane społecznie, kulturowo i politycznie:

Psychologia i nauka zwyczajowo traktuje percepcję jako zjawisko prywatne, ahistoryczne i apolityczne. (...) [z badań wynika], że percepcja jest podzielanym zjawiskiem społecznym - i jako takie posiada historię, jest polityczna (Howes 2005: 4-5).

Różnice mogą zachodzić także wewnątrz jednej kultury:

Podczas gdy, uogólniając, można mówić o modelu sensorycznym społeczeństwa w liczbie pojedynczej, w rzeczywistości, w tym samym czasie może istnieć wiele takich modeli. Są grupy wewnątrz społeczeństwa posiadające alternatywny sposób nadawania sensu światu. (...) Nowe światopoglądy rozwijają się, podczas gdy inne zanikają (Howes 2005: 11).

\footnotetext{
5 Arystoteles w pracy $O$ duszy udowadnia, że istnieje tylko pięć zmysłów: „o tym, że nie ma żadnego innego zmysłu oprócz pięciu (omówionych), tj. wzroku, słuchu, powonienia, smaku, dotyku, można przekonać się w następujący sposób. Jeśli postrzegamy to wszystko, co jest możliwe do postrzeżenia przez zmysł dotyku (bo wszystkie właściwości dotykalne, o ile są dotykalne postrzegamy przez zmysł dotyku), w takim razie, gdyby nam brakowało jakiegoś postrzeżenia, to z konieczności brakowałoby również jakiegoś postrzegającego organu". Filozof tworzy też hierarchię zmysłów, w której najważniejszą rolę odgrywa wzrok (visus), dalej słuch (auditus), zapach (odoratus), smak (gustus), zaś na samym jej dole znajduje się dotyk (tactus) (Jütte 2005: 53, 61).
} 
A zatem - jak wskazują Howes i Classen (1991: 259) - możliwe jest istnienie „odmiennych porządków sensorycznych właściwych różnym grupom funkcjonującym wewnątrz społeczeństwa, na przykład kobietom i mężczyznom, dzieciom i dorosłym, przywódcom i robotnikom, przedstawicielom różnych profesji”. Jednocześnie cytowanych badaczy nie interesują prywatne percepcje i jednostkowe wrażenia. Choć prowadzą badania terenowe, to jednak nie traktują idiosynkratycznych aspektów doświadczenia jako punktu wyjścia dla antropologii zmysłów - twierdzą, że kształt doświadczenia percepcyjnego jest zgodny ze wzorem dominującym w danym społeczeństwie i wyraża równowagę pomiędzy idiosynkratyczną specyfiką jednostki a narzucanymi społecznie normami (Howes 2003: 55). Ich zdaniem „dwie należące do tej samej kultury osoby mogą nie gustować w tych samych zapachach, jednak każda z nich będzie swe preferencje wyrażać w odniesieniu do zbioru z góry przyjętych kategorii" (Herzfeld 2004: 337). Howes precyzuje:

Należy podkreślić, że naszym celem nie jest analiza różnic indywidualnych w zakresie postrzegania zmysłowego (sensory mixes). Odmienności wynikające z wieku, płci, zawodu, temperamentu nabierają znaczenia tylko w kontekście kultury, do której jednostki przynależą. W taki właśnie sposób należy opisywać społeczeństwa jako bardziej wrażliwe na smak niż inne (np. zestawiając ze sobą upodobania Francuzów i Brytyjczyków), albo posiadające skłonności raczej słuchowe niż wizualne (np. w odniesieniu do doboru kanałów komunikacji przez przedstawicieli kultur niepiśmiennych, którzy do pewnego stopnia są zmuszeni polegać bardziej na słuchu niż na wzroku), oto podstawowe zainteresowanie antropologii zmysłów (Howes 1991b: 168).

Zgodnie z tym postulatem antropolodzy przyznają pierwszeństwo temu, co w percepcji kolektywne i kulturowe, nie zaś jednostkowe i przy padkowe. Dlatego też w poszukiwaniu danych analizują oni przede wszystkim język, kulturę materialną, mitologie, rytuały i kosmologie (Howes, Classen 1991: 261). W tekstach kultury, praktykach i artefaktach poszukują sensorycznych znaczeń i symboli.

W pracy Sensual Relations (2003) Howes wskazuje na koncepcję symbolu Lévi-Straussa jako istotną dla dalszego rozwoju kanadyjskiej antropologii zmysłów. Jak zauważa Dorota Angutek:

uczynił to nie bez racji, uwzględnił bowiem pomijany często przez polskich komentatorów (...) fakt, że konstruował on siatkę symboli często w korelacji z faktycznymi danymi topograficznymi lub fizykalnymi, które najpierw udzielały się znakom, a dopiero potem były kodyfikowane w mitologiczne symbole i nieuświadomione struktury znaczeniowe (Angutek 2010: 234).

W konsekwencji antropolodzy stawiają tezę o ścisłej zależności pomiędzy symbolicznym porządkiem kultury a strukturami wrażeniowymi i zmysłowymi, właściwymi określonej grupie etnicznej lub społecznej (Angutek 2010: 235; Howes 2005: 1-4). Jak pisze Howes (2003: 95): „Smaki, dźwięki i dotyk są nasycone 
znaczeniami, starannie porządkowane (hierarchized) i regulowane - wyrażają a jednocześnie ustanawiają porządek społeczny i kosmiczny".

Przedstawione wyżej założenia stanowią podstawę dla międzykulturowych badań porównawczych, których zadaniem jest dostarczenie danych pozwalających na rozwój teorii zmysłów. Zdaniem członków grupy Consert jedynie bliższe poznanie innych kultur i ich porządków sensorycznych pozwoli antropologii przełamać hegemonię wzroku i języka.

Na antidotum składa się ponowna mobilizacja naszych zmysłów, uznanie kultur za "sposoby postrzegania świata”, nauczenie się, jak posługiwać się nimi zgodnie z preferencjami badanych kultur - tak, aby nadać im sens (make some sense of them), zamiast poszukiwać rodzimych sposoby widzenia świata (world-view) (...) bez odnoszenia się do wszystkich zmysłów zaangażowanych w proces komunikacji (Howes 2003: 8).

Założenia te rozwijano konsekwentnie w trakcie kolejnych badań, dotyczących antropologii zapachu, estetyki, marketingu zmysłów, muzealnictwa i wystawiennictwa oraz nowych mediów. Antropolodzy opublikowali również szereg prac poświęconych poszczególnym modalnościom zmysłowym (Bull, Back 2003; Korsmeyer 2005; Classen 2005; Edwards, Baumik 2008, Howes 2009). Jednak już ich pobieżny przegląd ujawnia zmiany, jakie zachodzą w sposobie rozumienia antropologii zmysłów oraz tematyki jej zainteresowania. Jak wyraża to Howes (2003: 11):

Antropologia zmysłów rozpatruje związki i wzajemne oddziaływania zmysłów, a dalej ich kombinacje z organizacją społeczną i umownymi znaczeniami. Zmysły to najbardziej fundamentalna dziedzina kulturowej ekspresji; stanowią one medium, za pomocą którego wszystkie kulturowe wartości i społeczne praktyki są odtwarzane i przetwarzane. Każda dziedzina zmysłowego doświadczenia, począwszy od wzroku artysty, zapachu perfum czy smaku obiadu, jest przedłużeniem i rozwinięciem kultury. Obecnie wielu badaczy entuzjastycznie odkrywa, jak ruch, kolory czy zapachy są wehikułami kulturowych znaczeń, a nie tylko pobudzeniami zmysłów (...). Zmysły są także areną strukturyzacja społecznych ról i interakcji.

Tym samym na dalszy plan odchodzi projekt szeroko zakrojonych badań porównawczych. Stopniowo wzrasta również zainteresowanie zmysłowymi praktykami społeczeństw nowoczesnych. Kanadyjscy badacze wciąż są przywiązani do analizy dyskursu, choć w kolejnych pracach Howes dostrzega ograniczenia takich badań.

System wartości sensorycznych nigdy nie jest w pełni wyartykułowany poprzez język, ale jest praktykowany i doświadczany (czasami jest poddawany próbie) przez ludzi jako nośniki kultury. Porządek sensoryczny nie odnosi się jedynie do tego, co widać, słychać, jest raczej tym wszystkim, w czym człowiek żyje (Howes 2005: 3). 
Z czasem antropolodzy z Montrealu zaczynają dostrzegać związki zachodzące między poszczególnymi zmysłami. Zmienia się także ich sposób myślenia o roli zmysłów w refleksji antropologicznej. Zdaniem Howesa (2005: 4) zmysły nie są jedynie kolejną dziedziną badań, lecz stanowią raczej medium, dzięki któremu poznanie jest w ogóle możliwe. Jednocześnie badacze z tego kręgu konsekwentnie odżegnują się od perspektywy fenomenologicznej, pozostając wierni założeniom umiarkowanego relatywizmu kulturowego. Jak zauważa Angutek (2010: 232-233), wyrażają oni tezę o niewspółmierności doświadczenia zmysłowego przedstawicieli rozmaitych kultur, jednocześnie odcinają się od skrajnego relatywizmu pojęciowego, który wyklucza możliwość poznania kulturowych światów Innego.

\subsection{Amerykańska antropologia zmysłów}

W tym samym czasie, gdy zespół Consert tworzył program antropologii zmysłów, Paul Stoller i Nadia Seremetakis zaproponowali alternatywne podejścia do badań sensorycznych. Pierwsze z nich to propozycja fenomenologicznej antropologii zmysłowej. Nawiązując do fenomenologii percepcji Maurice'a Merleau-Pontego, Stoller kładzie nacisk na wielozmysłowy charakter wiedzy, która zapośrednicza materialne, społeczne i duchowe światy. Drugim jest stanowisko reprezentowane przez Seremetakis, rozpatrujące zmysłowy wymiar pamięci i świadomości historycznej w odniesieniu do kultury materialnej. Czerpiąc inspirację z prac Waltera Benjamina, antropolożka dostrzega wzajemne oddziaływanie sensorium, codziennego doświadczenia, percepcji i technologii typowej dla danego okresu historycznego.

Stoller od początku lat 70. aż do lat 90. XX wieku realizował badania terenowe wśród Songhajczyków zamieszkujących Republikę Nigru i Mali. Z kolei od 1992 roku prowadził badania w Nowym Jorku wśród imigrantów z Afryki Zachodniej. W książce The Taste of Ethnographic Things (1989), a następnie w Sensous Scholarschip (1997) analizuje zakres, w jakim badania etnograficzne stanowią przede wszystkim proces cielesny (corporeal process). Praca i bycie w terenie włączają etnografa nie tylko w świat wyobrażeń i wierzeń badanych, ale również w ich fizyczne otoczenie. Do tego wniosku doprowadziło Stollera (1997: 122) „głębokie doświadczenie świata Songhay", które wynikało nie tyle z wieloletniego pobytu w terenie, lecz nade wszystko z zanurzenia się w magię Songhaj, co było możliwe dzięki mianowaniu Stollera na sorko benya, czyli „niewolnika czarownika”. To zdarzenie pozwoliło mu wejść w zawiłą, wielowymiarową i wielozmysłową rzeczywistość Songhaj. W zrozumieniu roli zmysłów, głównie dźwięku, pomogła mu uwaga czarownika: „musisz nauczyć się [jak] słuchać, inaczej nie nauczysz się niczego na nasz temat" (Stoller 1984: 560). Zdaniem Stollera badania winny uwzględniać nie tylko przedmiot percepcji, lecz również kulturowo określone sposoby słuchania, wąchania, smakowania, dotykania i patrzenia. Podobnie jak Howes, Classen czy Synnott krytykuje on ograniczony i ograniczający charakter badań realizowanych przez zachodnich antropologów: 
Wnikamy naszymi zmysłami w świat Innego, nie pozwalamy jednak, aby on przeniknął nas samych. W rezultacie reprezentujemy rzeczywistość badanych ludzi poprzez nabrzmiałe dyskursy, które często w niewielkim stopniu oddają to, co staramy się opisać (Stoller 1989: 39).

Ta konstatacja jest punktem wyjścia dla projektu etnografii zmysłów, która jak pisze Jakub Walczak (2009: 113) - „miałaby unikać niebezpieczeństwa uwikłania się w etyczne (...) struktury pojęciowe”. Jak twierdzi Stoller, owo uwikłanie jest efektem obecnej w nauce spuścizny postkartezjańskiej filozofii. Dlatego też nauki społeczne dążą do ustalenia "statycznych uniwersaliów życia społecznego”, co może prowadzić do „złudzenia percepcji” i stawiania w centrum uwagi kwestii „całkowicie nieistotnych lub niezrozumiałych dla badanej społeczności” (Stoller 1980: 420). Według Stollera dzięki krytycznej wielozmysłowej obserwacji naukowiec może odejść od myślenia o danych jako zewnętrznych obiektach analizy i dostrzec, że percepcja jest dynamicznie połączona ze świadomością badacza (Walczak 2009: 113). Zadaniem antropologa jest odkrycie własnych, wynikających z socjalizacji uwarunkowań filozoficzno-kulturowych i podjęcie próby obserwacji etnograficznej rzeczywistości z perspektywy Innego. Jak twierdzi, zaproponowana przez niego „krytyczna, fenomenologiczna analiza może pomóc antropologom przełamać zaślepienie, wynikające z ich skłonności do obiektywizacji” (Stoller 1980: 427). Nowa orientacja badawcza miałaby uwrażliwić antropologów na obecność lokalnych epistemologii, a w ten sposób umożliwić im dostrzeżenie zjawisk, których obecność zazwyczaj jest przez nich ignorowana.

W jednym z artykułów Stoller pokazuje, na czym powinny polegać takie badania. W charakterystyczny dla siebie sposób opisuje, jak podczas pobytu w domu czarownika Adamu Jenitongo jego synowa podała fukko hoy - bezmięsny sos z ryżem, którego smak nie należał do przyjemnych. Zaserwowanie gościom niesmacznego dania stanowiło złamanie niepisanych zasad i przynosiło hańbę mieszkańcom domu, dla których gościnność jest jedną z najwyższych wartości (Stoller, Olkes 1986). Dla Stollera smak sosu jest przyczynkiem do głębszej analizy relacji, jakie zachodzą pomiędzy członkami domu gospodarza (w tym konkretnym przypadku jest on elementem oporu synowej wobec tradycji); jest też impulsem do rozmyślań nad miejscem smaku w filozofii europejskiej; w końcu prowadzi go do krytyki „niesmacznej” realistycznej nauki i stworzenia postulatu soczystej etnografii (tastefull ethnography):

Prowadząc soczyste badania terenowe, antropolog bada nie tylko system pokrewieństwa czy symbolizm, ale także z literackim zacięciem utrwala zapachy, smaki i tekstury ziemi, ludzi, jedzenia. Zamiast szukać ukrytych prawd, (soczysty) badacz terenowy (...) rozumie, że najgłębiej ukryte znaczenia, nieosiągalne wyżyny prawdy, mroczne otchłanie świadomości są tylko fikcją. Przyjmując soczystą, sensoryczną etnografię za punkt wyjścia, badacz terenowy studiuje indywidualne historie pojedynczych Songhajczyków, Negrów czy Trobriandczyków, zamiast badać całe kultury Songhay, Negrów czy Triobriand. Złożona relacja doświadczenia społecznego jednostek nadaje fakturę krajobrazowi notatek terenowych. Stąd pozornie pozbawione znaczenia wydarzenie, takie jak 
podanie gościom niesmacznego jedzenia, staje się równie ważne jak prowadzenie wywiadu $\mathrm{z}$ anonimowym informatorem na temat genealogii (...). W ten sposób badania etnograficzne wytwarzają głosy, autorytet i aurę autentyczności (Stoller 1989: 29).

Choć wielu badaczy prowadzi soczyste badania terenowe, to jednak spora część danych sensorycznych jest odrzucana podczas opracowywania ich wyników. Zdaniem Stollera tradycyjne pisarstwo etnograficzne redukuje doświadczaną i zmysłową rzeczywistość badanych (por. Stanton 2000: 284).

Antropolodzy, którzy postradali zmysły, piszą etnografię oderwaną od świata, który starają się sportretować. Pozbawione smaku teorie są dla nich ważniejsze niż smakowite sosy etnograficznego życia (savory sauces of ethnographic life) (Stoller 1994: 634).

W przeciwieństwie do tego soczysta etnografia jest deskryptywna, nieteoretyczna i łatwo wpada w ucho. Łączy też różnorodne składniki: dialogi, opisy, metafory, metonimie, synekdochy, ironię, zapachy, widoki i dźwięki, tworząc narrację, w której można poczuć świat Innego. Stollerowi nie chodzi jednak tylko o wzbogacenie prac etnograficznych o opisy zapachów, smaków czy dźwięków, lecz o przezwyciężenie etnocentryzmu i dostrzeżenie innych porządków sensorycznych, w których wzrok nie pełni naczelnej roli. Soczysta etnografia nie jest „czytaniem” lokalnej kultury, lecz poddaniem się jej oddziaływaniu. To właśnie sposób bycia w terenie oraz jego opisu ma wprowadzić czytelnika prac antropologicznych w nowy, inspirujący świat, nie tylko poprzez eksperymenty w zakresie struktury narracyjnej, ale również poprzez zmianę języka samej etnografii (Stoller 1989: 51).

Nadia Seremetakis, podobnie jak Stoller, opowiada się za autorefleksyjną epistemologią w obrębie badań antropologicznych, a także potraktowaniem doświadczeń i odczuć badacza jako pełnoprawnego źródła wiedzy. Jej prace są nasycone sensualnymi wspomnieniami z dzieciństwa, dotyczącymi smaku brzoskwini rodhákino czy zapachu i tekstury babcinej sukni (Seremetakis 1994: 1-4). Osobiste historie stanowią bazę do analizy tego, jak indywidualna i kolektywna pamięć wpisuje się w sensualne własności przedmiotów. Propozycja Seremetakis nie ogranicza się jedynie do studiów nad biografią rzeczy. Antropolożka cofa się pamięcią do czasów dzieciństwa, przywołuje niewyraźne obrazy, ożywia je, nadając im fakturę, zapach, kolor i ostrość:

Babcia siedzi na drewnianym taborecie, jej twarz jest ogorzała, włosy upięte w kok, dłonie piegowate i szorstkie. Dziecko wślizgnęło się na jej kolana. To czas na bajki. Wejść na jej kolana to wkroczyć w otoczenie różnorodnych zapachów i tekstur, śladów jej pracy w polu, kuchni, przy zwierzętach (Seremetakis 1994: 30).

Poprzez odwołanie się do osobistych wspomnień i artefaktów autorka dociera do często zakamuflowanych, choć postrzeganych zmysłowo dyspozycji tradycyjnych społeczności. Doskonałym przykładem obrazującym to podejście jest 
historia „brzoskwini Afrodyty” opisana w tekście, którego polskie tłumaczenie prezentujemy w niniejszym numerze „Etnografii”:

Dorastałam z brzoskwinią. Jej skórkę pokrywał puszek w kolorze matowej złamanej bieli na przemian z odcieniami różu. Nazywała się rodhákino (ródho znaczy róża). Była ładnie zaokrąglona i gładka jak mała gliniana miseczka, doskonale dopasowana do kształtu dłoni. Jej miąższ był jędrny, ale wilgotny, stawiał miękki opór zębom. Trochę słodka i trochę kwaśna, wydzielała charakterystyczny zapach. Ta brzoskwinia znana była pod nazwą "pierś Afrodyty" (o mastós tis Afrodhítis) (Seremetakis 1994: 1).

Podczas wieloletniego pobytu w Stanach Zjednoczonych Seremetakis pielęgnowała wspomnienie tej konkretnej odmiany brzoskwini. Każdy powrót do Grecji był naznaczony jej smakiem. Jednak w pewnym momencie badaczka uświadomiła sobie jej zniknięcie. Pomimo obfitości odmian i gatunków, jakie wypełniały stoiska na bazarkach i w supermarketach, rodhákino okazało się niedostępne. Te z pozoru nieistotne zdarzenia, ulotne wrażenia i wspomnienia służą Seremetakis do refleksji na temat zmian, jakie zachodzą w Grecji pod wpływem makropolityki ówczesnej Europejskiej Wspólnoty Gospodarczej oraz szerszych przemian w gospodarce (np. masowej uprawy roślin, rezygnacji z odmian nieodpornych na transport i długotrwałe przechowywanie). Antropolożka stara się uświadomić czytelnikom, że zmiany w obrębie percepcji sensorycznej są niemal „niezauważalne”, a także ujawniają się po fakcie w bajkach, mitach, wspomnieniach, na obrzeżach codziennych rozmów (Seremetakis 1994: 13). Tym, co może zostać utracone w wyniku globalizacji, są nie tylko produkty, ale również ich smak, zapach, tekstura, a razem z nimi pamięć sensoryczna konkretnych społeczności, będąca elementem ich wspólnych praktyk oraz kulturowego dziedzictwa.

Seremetakis - podobnie jak Stoller - dla opisu tych zjawisk poszukuje nowych form wypowiedzi. W swoich pracach wykorzystuje montaż - łączy ze sobą małe opowieści, sceny z życia, wspomnienia, wrażenia. Ich celem jest naśladowanie, przeżycie i przyswojenie badanych zjawisk, a następnie opisanie ich w taki sposób, aby wywołać u odbiorcy określone emocje, wyobrażenia i wspomnienia. To właśnie w największej mierze odróżnia ich działania od projektu antropologów z Kanady, których przed mimetyzmem i utratą dystansu wobec badanych kultur ma chronić relatywizm kulturowy (por. Angutek 2010: 233). Chociaż wkład Stollera i Seremetakis w rozwój antropologii zmysłów jest niezaprzeczalny i znajduje licznych kontynuatorów, to sami zainteresowani od końca lat 90. XX wieku nie włączają się w debaty na temat przyszłości i kształtu subdyscypliny.

\section{Krytyka antropologii zmysłów i sensoryczna antropologia}

Antropologia zmysłów w zasadzie od samego początku swego istnienia była poddawana krytyce. Szczególnie intensywne okazały się tarcia w obrębie samej subdyscypliny. Wewnętrzne spory dotyczyły różnic w podejściu do badań 
sensorycznych. Bliższa analiza publikacji wpisujących się w nurt antropologii zmysłów świadczy przede wszystkim o głębokim rozdarciu pomiędzy amerykańską i kanadyjską wersją subdyscypliny. Nieporozumienia wynikają nie tyle z przyjęcia różnych założeń teoretycznych i metodycznych, ile raczej z posługiwania się odrębnym, niezrozumiałym dla drugiej strony językiem.

Howes krytykuje zarówno propozycję "soczystej etnografii”, jak i koncepcję badań nad pamięcią sensoryczną. Jego zdaniem, nawet jeśli Stoller łączy w swoich pracach świadomość i wrażeniowość, rozumowość i zmysłowość, w rzeczywistości nie wykracza poza zachodni sposób myślenia, nie potrafi przekroczyć własnych ograniczeń - nadmiernie podkreśla doświadczenia zmysłowe bez szerszego uwzględnienia zbiorowych symboli i znaczeń sensorycznych (Howes 2003: 42).

Z kolei w pracach Seremetakis Howes dostrzega nadmierne przywiązanie do przedmiotów. W jego ocenie traktowanie ich jako „wyrażających własną sensoryczną historię" $\mathrm{i}$ „pokrytych emocjonalnym i historycznym osadem” (Seremetakis 1994: 7) prowadzi do dziwacznej iluzji kultury materialnej jako sfery wielozmysłowego zapisu (Howes 2003: 44). W efekcie przedstawione historie wydają się statyczne, przyjmują własności obiektów, w których są zawarte. Dla Howesa wewnętrzne jakości przedmiotów nie wyrażają ich historii - to w ludziach, którzy wchodzą z nimi w interakcję, gromadzą się wspomnienia i znaczenia. Poza tym, kładąc zbyt duży nacisk na wspomnienia, Seremetakis sugeruje, że znaczenia sensoryczne krystalizują się w przeszłości. Według Howesa taka konstatacja jest błędna, ponieważ tym, co nadaje przedmiotom ich znaczenia, są nie tylko związane z nimi wspomnienia, lecz także to, w jaki sposób są one doświadczane na co dzień. Kanadyjski badacz krytykuje również odrzucenie refleksji nad tym, jak zjawiska sensoryczne mogą funkcjonować w postaci symboli utrwalonych w zbiorowej i indywidualnej pamięci (Howes 2003: 43-44).

Co jednak ważniejsze, to właśnie kanadyjska wersja antropologii zmysłów spotkała się z największą krytyką, nie tylko ze strony Stollera czy Seremetakis, którzy wskazali na ograniczenia międzykulturowych badań porównawczych, pomijających jednostkowe doświadczenie. Nowatorski w swoim czasie projekt Howesa relatywnie szybko został uznany za podejście tradycjonalistyczne (Pink 2010: 332). Krytyczne nastawienie przyjęli przede wszystkim badacze niezwiązani bezpośrednio z powstaniem subdyscypliny oraz podejmujący tematykę zmysłów w późniejszych latach, gdy program Consert był już częściowo skrystalizowany. Najczęściej przytaczana krytyka antropologii zmysłów spod znaku Howesa została wyrażona przez Tima Ingolda (2000: 243-287), a następnie w ramach debaty, jaka odbyła się na łamach „Social Anthropology / Anthropologie Sociale". Ingold podważa jej fundamentalne założenie o kulturowym charakterze percepcji. Jak pisze, „upierając się, że tubylcze paradygmaty same w sobie są produktami kulturowymi, Howes w rzeczywistości ogranicza możliwość ich poznania" (Ingold 2011a: 315). Zdaniem Ingolda trudno wyobrazić sobie paradygmat, który byłby bardziej kulturowy i w większym stopniu historyczny niż ten, który zakłada, że paradygmaty innych, niezależnie od tego, czy tubylcze, czy naukowe, są w gruncie rzeczy wytworem kultury. 
Antropologia zmysłów, według której percepcja składa się z modelowanych kulturowo, dostarczonych ciału wrażeń, może mieć niewiele do powiedzenia na temat tego, jak ludzie w rzeczywistości patrzą, słuchają, dotykają, smakują i wąchają. Z drugiej strony, może powiedzieć wszystko o tym, jak doświadczenie widzenia, słyszenia, czucia, karmi wyobraźnię i wtapia się w dyskurs oraz ekspresje literackie. (...) Oto przesunięcie uwagi od analizy tego, jak ludzie postrzegają zamieszkiwany przez siebie świat, do refleksji nad tym, jak zamieszkują wirtualne światy zmysłów (Ingold 2011a: 315).

Według Ingolda słabość tej koncepcji wynika z koncentracji na abstrakcyjnych, bezcielesnych „ideach” i „wierzeniach”, a także uznania doświadczenia sensorycznego za medium wyrażające pozazmysłowe wartości (Ingold 2000: 156). W jego ocenie podejście to redukuje ciało do roli pojemnika, zaś rolę zmysłów sprowadza do nośnika ładunków semantycznych projektowanych przez kolektywny, ponadzmysłowy podmiot - społeczeństwo (Ingold 2000: 284). W ten sposób, pomimo licznych deklaracji, kanadyjski projekt nie zrywa z dualizmem zawartym w kartezjańskiej teorii poznania, według której „ludzie nadają sens rzeczom i światu poprzez nakładanie gotowych znaczeń na powierzchnię żywego doświadczenia, aby przy użyciu symboli ukształtować chaotyczny materiał surowych wrażeń (Ingold 2011b: 326). Brytyjski antropolog nie zgadza się z Howesem, gdy ten twierdzi, że należy przekroczyć podejście fenomenologiczne w badaniach nad percepcją, pozwalające jedynie na "czucie świata” (sensing the world), na rzecz zrozumienia „sposobów czucia świata” (ways of sensing the world) (Howes 2003: 32-34). Ingold sugeruje przeformułowanie subdyscypliny - od badań nad „świadomością sensoryczną społeczeństw” w kierunku „twórczego i żywego splotu doświadczenia i dyskursu, a także analizy wpływu konstrukcji dyskursywnych na postrzeganie otaczającego świata" (Ingold 2000: 285). Jak pisze w innym miejscu, ,jeśli chcemy zrozumieć, jak powstają znaczenia, musimy zacząć od życia społecznego, nie zaś od kulturowych modeli danej kultury" (Ingold 2011b: 326).

Przedstawiona wyżej krytyka jest wyrazem pęknięcia w obrębie subdyscypliny, które powstało na przełomie lat 80. i 90. XX wieku. Z jednej strony antropologia zmysłów była rozumiana jako szeroko zakrojony projekt badań porównawczych nad symbolami sensorycznymi, z drugiej zaś, została utożsamiona z badaniami nad doświadczeniem. Phillipe Vannini, Dennis Waskul i Simon Gottschalk (2012: 18) stwierdzają, że wielu antropologów zajmujących się tą tematyką prowadzi badania w izolacji, bez uwzględniania zmian zachodzących w pokrewnych dyscyplinach. Zamiast tego autorzy skłaniają się ku badaniom antropologicznych, które

(...) powstają w efekcie eksperymentów i fuzji nowych podejść teoretycznych, konceptualnych, rzeczowych, metodologicznych i dyscyplinarnych. Pobudzają one nowe epistemologie i ontologie, które w mniejszym niż do tej pory stopniu oparte są na języku, w większym natomiast na ucieleśnionych, wielozmysłowych, wielomodalnych, preobiektywnych i cielesnych źródłach wiedzy (Vannini, Waskul, Gottschalk 2012: 18). 
Również Sarah Pink zastanawia się nad stanem współczesnej refleksji nad zmysłami. Jej zdaniem należy dokonać rozróżnienia pomiędzy antropologią zmysłów (anthropology of the senses) i sensoryczną antropologią (sensory anthropology):

Sensoryczna antropologia ma swoje korzenie w charakterystycznych dla antropologii zmysłów badaniach nad percepcją, a zarazem odchodzi od nich. Gdy ta pierwsza angażuje się bezpośrednio w badania interdyscyplinarne, ta druga jest bardziej specjalistyczna. (...) W tym sensie antropologię zmysłów można potraktować jako podrzędną względem antropologii sensorycznej (Pink 2010: 331).

Pink stara się uchwycić i nazwać podejścia teoretyczne i badawcze, które wykraczają poza ramy programowe stworzone przez kanadyjskich antropologów. Sensoryczną antropologię opisuje jako podejście interdyscyplinarne otwarte na teorie, metody i koncepcje wypracowane w obrębie innych dyscyplin, czasem nawet tak odległych od antropologii, jak neurologia czy sztuka (Pink 2010: 331-332). Tego typu badania są inspirowane nie tylko przez tubylcze teorie percepcji (Howes), lecz również założenia wypracowane w obrębie zachodniej filozofii, psychologii, antropologii. Tak sprofilowany sposób rozumienia zmysłów nawiązuje do fenomenologii (Maurice Merleau-Ponty, Thomas Csordas), ekologii psychologicznej (James Gibson, Tim Ingold), teorii praktyki (Pierre Bourdieu) i non-reprsentational theory (Nigel J. Thrift). Antropologia sensoryczna jest wrażliwa na kwestie podejmowane we współczesnej humanistyce, takie jak refleksyjność, gender, materialność, ucieleśnienie, wizualność, cyfrowość. W jej ramach zmysły nie są rozpatrywane $\mathrm{w}$ odosobnieniu (antropologia smaku, zapachu, dotyku), lecz w relacjach, jakie zachodzą pomiędzy ich poszczególnymi modalnościami, ciałem, umysłem a środowiskiem.

Propozycja Pink wyrasta przede wszystkim z inspiracji pracami Ingolda, Stollera czy Seremetakis, ale także Laury Marks, Kathryn Linn Guerts i Davida MacDougalla, będąc odpowiedzią na ograniczenia teoretyczne, metodologiczne i konceptualne propozycji Howesa. Antropolożka jest rozczarowana stanem wiedzy na temat procesu badawczego, o którym niewiele napisano w klasycznych pracach w pisujących się w nurt antropologii zmysłów. Stara się wypełnić tę lukę, tworząc koncepcję sensorycznej etnografii (sensory ethnography) (Pink 2009: 2), której postulaty mogą stanowić wyzwanie dla współczesnych badaczy:

Realizacja etnografii sensorycznej pociąga za sobą konieczność podjęcia serii konceptualnych i praktycznych kroków powalających badaczowi przemyśleć na nowo zarówno już istniejące, jak również nowe - oparte na uczestnictwie i współpracy - techniki badań etnograficznych, za pomocą terminów percepcji zmysłowej, znaczenia, wartości, źródeł wiedzy i praktyk. Zakłada ona samoświadomość badacza oraz refleksyjne podejście do percepcji w trakcie całego procesu badawczego, na który składają się: planowanie, rekonesans, praca terenowa, analiza i praktyki z zakresu reprezentacji wiedzy (Pink 2009: 10).

Antropolożka analizuje, w jakim stopniu tradycyjne metody badań, takie jak wywiad swobodny i obserwacja uczestnicząca, są w gruncie rzeczy 
wielozmysłowym wydarzeniem, doświadczeniem angażującym zarówno badacza, jak i badanych. Badaczka proponuje wzbogacenie antropologicznej skrzynki z narzędziami o nowe metody i techniki badań, takie jak głębokie słuchanie (deep listening), patrzenie oparte na umiejętnościach (skilled vision) czy doświadczenie uczestniczące (participatory experience). Szansę dla rozwoju etnografii sensorycznej upatruje również w użyciu nowych technologii (aparaty i kamery cyfrowe, rejestratory), a także badaniach opartych na współpracy z respondentami. Antropolożka zwraca również uwagę na konieczność rozszerzenia spektrum modeli reprezentacji wiedzy:

Etnograf sensoryczny (...), który pragnie umieścić swoją pracę w istniejących trajektoriach dyscypliny, musi stawić czoła dwóm zasadniczym wyzwaniom. Pierwsze z nich oznacza znalezienie właściwego (być może nowego) sposobu przekazywania wiedzy na temat doświadczenia zmysłowego, umiejscowienia, kategorii sensorycznych - zarówno własnych, jak i badanych osób. Drugie z nich pociąga za sobą włączenie eksperymentalnych form $\mathrm{w}$ proces tworzenia prac naukowych, które będą zarazem teoretyczne (przyczynią się do rozwoju debaty akademickiej), rzetelne (pozwalają uzupełnić wiedzę na konkretny temat) i zaangażowane (staną się bazą dla interwencji społecznych) (Pink 2009: 133).

Pink pragnie uzupełnić antropologiczne pisarstwo o nowe sposoby prezentacji wyników badań, takie jak poezja, łączenie różnorodnych stylów pisania, ale także kompozycje, film, wideo, teksty hipermedialne czy instalacje. Choć zaproponowane przez nią podejście jest inspirujące, to jednak ona sama jedynie w ograniczonym zakresie realizuje własne postulaty. Jej prace dotyczą przede wszystkich rozwiązań metodycznych, niewiele natomiast dowiemy się z nich o jej sposobie rozumienia zmysłów czy przyjętej przez nią teorii percepcji. W tym względzie antropolożka odsyła czytelników do innych autorów, w tym Ingolda, stąd też lekturze jej publikacji towarzyszy poczucie niedosytu i niekonsekwencji.

W ostatnich latach pojawiły się również próby łączenia ze sobą stanowisk reprezentowanych przez antropologów z Kanady oraz zwolenników antropologii sensorycznej. Jedną z nich jest propozycja japońskiego badacza Keizo Miyasaka (2011: 202), który dostrzega ewolucję myśli Howesa oraz jej stopniowe zbliżanie się do idei antropologii sensualnej w wydaniu Pink. Rzeczywiście, w pochodzącej z 2009 roku pracy The Sixth Sense Reader Howes opowiada się za zastąpieniem pojęcia „zmysły” określeniem „sensorium”. W ten sposób stara się przezwyciężyć modernistyczny podział na umysł i ciało, świadomość i czucie; podejmuje też próbę włączenia do swojego podejścia społeczno-kulturowej fenomenologii. Wciąż jednak pozostaje wierny kluczowym założeniom kanadyjskiej antropologii zmysłów (Howes 2009: 1).

Miyasaka nie poprzestaje na analizie dotychczasowych rozważań na temat antropologicznej refleksji nad zmysłami, lecz przedstawia własny projekt „,zmysłowej antropologii" (sensorial anthropology), która ma stanowić pomost pomiędzy klasyczną już antropologią zmysłów oraz sensoryczną antropologią: 
(...) podejście pośredniczące między antropologią zmysłów i sensoryczną antropologią może okazać się owocne dzięki stworzeniu przestrzeni dla kreatywnych działań, przy jednoczesnym uwzględnianiu analitycznych niejednoznaczności charakterystycznych dla skrajnych stanowisk, pozwoli także uchwycić doświadczenie z naciskiem na wewnętrzne współdziałanie zmysłów. Użyliśmy koncepcji zmysłowej antropologii (sensorial anthropology), aby w ten sposób ująć cały zakres podejść wyrastających pomiędzy biegunami wyznaczonymi przez Howesa z jednej strony, z drugiej zaś przez Pink i Ingolda (Miyasaka 2011: 218).

Miyasaka nie stawia ostrej granicy pomiędzy projektem Howesa i zespołu Consert a wizją antropologii podzielaną przez Pink, Ingolda, Stollera czy Seremetakis. Opowiada się raczej za podejściem respektującym zarówno dorobek teoretyczny i metodologiczny wypracowany w ramach badań porównawczych, jak i prace oparte na założeniach fenomenologii percepcji:

Jesteśmy w stanie opowiadać się za daleko bardziej wyrafinowanym modelem funkcjonowania sensorium, dzięki uwzględnieniu aspektu kulturowego, a jednoczenie zakresu, w jakim jest on wcielony (embodied) w ludzką percepcję, działanie i doświadczenie. Tak rozumiane sensorium współgra z logiką i wrażliwością, rozumem i emocjami, czy wreszcie umysłem i ciałem (Miyasaka 2011: 218).

Japoński antropolog stara się przełamać klasyczne dychotomie oddzielające nauki przyrodnicze od humanistycznych. Jego propozycja stanowi pomost pomiędzy dotychczasowymi dokonaniami przedstawicieli subdyscypliny a wizjonerskim projektem sensorycznej antropologii. W podobnym kierunku podąża Kathryn Linn Geurts (2003), łączy ze sobą analizę lingwistyczną z badaniami fenomenologicznymi. Choć tak rozumiana „droga środka” może prowadzić do interesujących rezultatów, dostrzegamy jednak związane z nią ograniczenia i niebezpieczeństwa, w tym ignorowanie różnic zachodzących pomiędzy zespalanymi stanowiskami oraz wynikające $z$ tego uproszczenia poznawcze czy teoretyczne. Jak bowiem sądzimy, prezentowane perspektywy wyrastają z dwóch odmiennych paradygmatów i wizji antropologii, stąd też przezwyciężenie ich rozbieżności może okazać się znacznie trudniejsze, niż zakładają to autorzy przedstawionych wyżej postulatów.

\section{Zakończenie}

Z przedstawionego przeglądu podejść badawczych, które odnoszą się do antropologicznych badań nad zmysłami, wyłania się niejednoznaczny charakter subdyscypliny. Wśród wymienionych autorów nie ma zgody co do sposobu pojmowania zmysłów, ich roli czy relacji z pozostałymi składnikami ludzkiego życia, jak również formy prowadzenia badań w obrębie tej tematyki oraz prezentowania ich wyników. Brenda Farnell (203: 133), analizując dotychczasowe dokonania antropologów, zauważa, że każda teoria zmysłów zakłada teorię percepcji - to ona warunkuje rozumienie ich znaczenia i funkcjonowania, a w konsekwencji także 
sposoby ich badania. Problem w tym, że fundatorzy antropologii zmysłów czy sensorycznej antropologii nie zawsze piszą wprost o przyjętych przez siebie założeniach dotyczących natury poznania. Tym samym omawiane prace stanowią raczej inspirującą mozaikę autorskich propozycji teoretycznych i metodologicznych, niż wyraz wspólnego stanowiska czy oglądu zmysłowości, a także szerzej kulturowej i społecznej rzeczywistości.

\section{Literatura}

Angutek, D. (2010). Kanadyjska antropologia zmysłów - alternatywa wobec postmodernizmu. Lud, 94, 221-242.

Angutek, D. (2013). Kulturowe wymiary krajobrazu. Antropologiczne studium percepcji przyrody na prowincji: do teorii do empirii. Poznań: Bogucki Wydawnictwo Naukowe.

Benedict, R. (1966). Wzory kultury. Przeł. J. Prokopiuk. Warszawa: PWN.

Benedict, R. (1999). Chryzantema i miecz. Wzory kultury japońskiej. Przeł. E. Klekot. Warszawa: Polski Instytut Wydawniczy.

Brocki, M. (2008). Literatura - Dialog - Przekład. Wrocław: Wydawnictwo Katedry Etnologii i Antropologii Kulturowej UWr.

Bull, M., Back, L. (eds.) (2003). The Auditory Culture Reader. Oxford - New York: Berg.

Carpenter, E. (1972). Oh, What a Blow That Phantom Gave Me!. New York: Holt, Rinehart, and Winston.

Carpenter, E., Varley, F., Flaherty, R. (1958). Eskimo. Toronto: University of Toronto Press.

Classen, C. (1993). Worlds of Sense: Exploring the Senses in History and across Cultures. London - New York: Routledge.

Classen, C. (1997). Foundations for an anthropology of the senses. International Social Science Journal, 49 (153), 401-412.

Classen, C. (2012). The Deepest Sense: A Cultural History of Touch. Studies in Sensory History. Chicago - Springfield: University of Illinois Press.

Classen, C. (ed.) (2005). Book of Touch. Oxford - New York: Berg.

Dundes, A. (1980). Interpreting Folklore. Bloomington: Indiana University Press.

Edwards, E., Baumik, K. (eds.) (2008). Visual Sense: A Cultural Reader. Oxford - New York: Berg.

Farnell, B. (2003). Kinestetic, Sense and Dynamically Embodied Action. Journal for the Anthropological Studies of Human Movement, 12 (4), 132-144.

Geertz, C., (2003). Opis gęsty - w stronę interpretatywnej teorii kultury. Przeł. S. Sikora. W: M. Kempny, E. Nowicka (red.), Badanie kultury. Elementy teorii antropologicznej (s. 35-58). Warszawa: Wydawnictwo Naukowe PWN.

Geurts, K.L. (2003). Culture and Senses: Bodily Ways of Knowing in an African Community. Berkley: University of California Press.

Haddon, A.C. (1903). Reports of the Cambridge Anthropological Expedition to Torres Straits. Vol. II. Cambridge: University Press. http://archive.org/stream/reportsofcambrid02hadd\#page/n7/mode/2up [dostęp: 09.11.2012].

Haddon, A.C. (1978). Head-hunters. New York: AMS Press.

Hall, E.T. (2009). Ukryty wymiar. Przeł. T. Hołówka. Warszawa: Muza.

Herzfeld, M. (2004). Antropologia. Praktykowanie teorii w kulturze i społeczeństwie. Przeł. M.M. Piechaczek. Kraków: Wydawnictwo UJ. 
Howes, D. (1991a). Introduction: 'To Summon All the Senses). W: D. Howes (ed.), The Varieties of Sensory Experience A Sourcebook in Anthropology of the Senses (s. 3-21). Toronto - Buffalo - London: University of Toronto Press.

Howes, D. (1991b). Sensorial Anthropology. W: D. Howes (ed.), The Varieties of Sensory Experience A Sourcebook in Anthropology of the Senses (s. 167-191). Toronto - Buffalo London: University of Toronto Press.

Howes, D. (2003). Sensual Relations. Engaging the Senses in Cultural and Social Theory. Michigan: The University of Michigan Press.

Howes, D. (2005). Introduction: Empires of the Senses. W: D. Howes (ed.), Empire of the Senses. The Sensual Culture Reader (s. 1-17). Oxford - New York: Berg.

Howes, D. (2009). Introduction: the revolving sensorium. W: D. Howes (ed.), The Sixth Sense Reader (s. 1-52). Oxford - London: Berg.

Howes, D. (2010). Response to Sarah Pink. Social Anthropology / Anthropologie Sociale, 18 (3), 333-336.

Howes, D. (2012). The Craft of the Senses. http://centreforsensorystudies.org/wp-content/ uploads/2012/08/Craft-of-the-Senses.pdf [dostęp: 07.10.2012].

Howes, D. (ed.) (2009). The Sixth Sense Reader. Oxford - New York: Berg.

Howes, D., Classen, C. (1991). Conclusion. Sounding Sensory Profiles. W: D. Howes, C. Classen (eds.), The Varieties of Sensory Experience. A Sourcebook in Anthropology of the Senses (s. 257-288). Toronto - Buffalo - London: University of Toronto Press.

Howes, D., Classen, C. (b.d.), Doing sensory anthropology. http://www.sensorystudies.org/ sensorial-investigations/doing- sensory-anthropology/ [dostęp: 05.10.2012].

Howes, D., The Varieties of Sensory Experience: A Comparative Study of the Influence of Culture on the Ratio or Balance beetween the Senses (1988-1990). http://www.david-howes.com/ senses/Consert-Variety.htm [dostęp: 03.09.2012].

Ingold, T. (2000). The Perception of the environment: essays on livelihood, dwelling and skill. London: Routledge.

Ingold, T. (2011a). World of sense and sensing the world: a response to Sarah Pink and David Howes. Social Anthropology / Anthropologie Sociale, 19 (3), 313-317.

Ingold, T. (2011b). Repley to David Howes. Social Anthropology / Anthropologie Sociale, 19 (3), 323-327.

Jütte, R. (2005). A History of the Senses. From Antiquity to Cyberspace. Cambridge - Malden: Polity Press.

Korsmeyer, C. (ed.) (2005). The Taste Culture Reader: Experiencing Food and Drink. Oxford New York: Berg.

Leach, E. (2010). Kultura i komunikowanie. Przeł. M. Buchowski. Warszawa: Wydawnictwo Naukowe PWN.

Lévi-Strauss, C. (2010). Surowe i gotowane. Przeł. M. Falski. Warszawa: Aletheia.

McLuhan, M. (2001). Wybór tekstów. Przeł. E. Różalska, J. M. Stokłosa. Poznań: Wydawnictwo Zysk i S-ka.

McLuhan, M. (2010). Przestrzeń wizualna i akustyczna. Przeł. J. Kutyła. W: Ch. Cox, D. Warner (red.), Kultura dźwięku. Teksty o muzyce nowoczesnej (s. 95-101). Gdańsk: słowo/obraz terytoria.

Mead, M., Métraux, R. (1953). Introduction. W: M. Mead, R. Métraux (eds.), The Study Culture at a Distance (s. 3-53). Chicago: University of Chicago Press.

Métraux, R. (1953). Resonance in Imagery. W: M. Mead, R. Métraux (eds.), The Study Culture at a Distance (s. 343-362). Chicago: University of Chicago Press.

Misiak, T. (2007). Od przestrzeni akustycznej do akustycznej cyberprzestrzeni. Styszenie w refleksji filozoficznej a muzyka elektroniczna. http://kaleka.net/files/ 
od_przestrzeni_akustycznej_do_akustycznej_cyberprzestrzeni.\%20doc [dostęp: 15.10.2012].

Miyasaka, K. (2011). Positioning Sensorial Anthropology in Relevance to Logic and Sensibilities Research. CARLS Series of Advanced Study of Logic and Sensibility, 5, 197-220.

Olszewska-Dyoniziak, B. (2003). Człowiek - Kultura - Osobowość. Wstęp do klasycznej antropologii kulturowej. Wrocław: ALTA 2.

Ong, W. (1967). The presence of the word: Some prolegomena for cultural and religious history. New Haven: Yale University Press.

Ong, W. (1977). Interfaces of the Word. Ithaca: Cornell University Press.

Ong, W. (1992). Oralność i piśmienność. Stowo poddane technologii. Przeł. J. Japola. Lublin Wydawnictwo KUL.

Ong, W. (2003). Psychodynamika oralności. Przeł. J. Japola. W: G. Godlewski (red.), Antropologia stowa: zagadnienia i wybór tekstów (s. 191-202). Warszawa: Wydawnictwo UW.

Pink, S. (2009). Doing Sensory Ethnography. London: Sage.

Pink, S. (2010). The future of sensory anthropology / the anthropology of the senses. Social Anthropology / Anthropologie Sociale, 18 (3), 331-333.

Porter, R. (1986). Foreword. W: A. Corbin, The Foul and the Fragrant: Odor and the French Social Imagination. New York: BERG.

Prins, H.E., Bishop, J. (2001). Edmund Carpenter: Explorations in Media and Anthropology. Visual Anthropology, 17 (2), 110-140.

Ritchie, I. (1991). Fusion of the Faculties: A Study of the Language of the Senses in Hausaland. W: D. Howes (ed.), The Varieties of Sensory Experience A Sourcebook in Anthropology of the Senses (s. 192-202). Toronto - Buffalo - London: University of Toronto Press.

Sendyka, R. (2011). Antropologia zmysłów. Autoportret, 3 (35), 20-27.

Serementakis, N.C. (1994). The Senses Still. Perception and Memory as Material Culture in Modernity. Chicago - London: University of Chicago Press.

Stanton, G. (2000). The way of the body: Paul Stoller's search for sensuous ethnography. European Journal of Cultural Studies, 3 (2), 259-277.

Stoller, P. (1980). The Negotiation of Songhay Space: Phenomenology in the Heart of Darkness. American Ethnologist, 7 (3), 419-431.

Stoller, P. (1984). Sound in Songhay Cultural Experience. American Ethnologist, 11 (3), 559-570.

Stoller, P. (1989). The Taste of Ethnographic Things: The Senses in Anthropology. Philadelphia: University of Pennsylvania Press.

Stoller, P. (1994). Embodying Colonial Memories. American Anthropologist, 96 (3), 634-648.

Stoller, P. (1997). Fusion of the Worlds. An Ethnographic Possession among the Songhay of Niger. Chicago - London: The University of Chicago Press.

Stoller, P., Olkes, Ch. (1986). Bad Sauce, Good Ethnography. Cultural Anthropology, 1 (3), 336-352.

Synnott, A. (1993). The Body Social. London - New York: Routledge.

Tyler, S. (1986). Post-modern Ethnography. From Document of the Occult to Occult Document W: J. Clifford, G. Marcus (eds.), Writting Culture (s. 122-140). Berkeley: Univeristy of California Press.

Vannini, P., Waskul, D., Gottschalk, S. (2012). The Senses in Self, Society, and Culture. A Sociology of the Senses. New York - London: Routledge.

Walczak, B. (2009). Antropolog jako Inny. Od pierwszych badań terenowych do wyzwań ponowoczesnej antropologii. Warszawa: Wydawnictwo Naukowe Scholar. 


\section{SUMMARY}

Anthropology of the Senses and Sensory Ethnography - Genesis, Assumptions, Research Approaches

The article presents basic inspirations, beginnings and development of the anthropology of the senses and sensory ethnography. The main aim is to show the most influential scholars who have had a significant impact on the anthropological debate regarding human sensuality and perception and its connections with culture. The authors discuss general possibilities of this kind of reflection within cultural and social anthropology, as well as the fundamental differences between scholars undertaking such research.

Keywords: anthropology of the senses, sensory ethnography, embodiment, Concordia Sensoria Research Team 